\title{
Fish assemblage structure is consistent through an annual hydrological cycle in habitats of a floodplain-lake in the Colombian Amazon
}

\author{
Sandra Bibiana Correa
}

I investigated changes in abundance and spatial distribution of medium- and large-sized fishes ( $>100 \mathrm{~mm})$ in an oxbow lake of the lower Apaporis River, Colombian Amazon, across three seasons (falling, low, and rising water). Fifty-three species in 13 families were collected from six habitats: lagoon channels, stream, flooded forests, isolated shrub patches, muddy beaches, and rocks. Abundance, biomass, and species richness were higher during the rising-water season and lower during fallingwater season. Correspondence analysis (CA) showed that fish assemblages were associated to two basic habitat types. One assemblage of fishes was associated with densely vegetated and structurally complex habitats (flooded forest, lagoon channels, stream, and isolated shrub patches), and a second assemblage of fishes was associated with muddy beaches. These assemblages persisted despite seasonal fluctuations in water level. Species in the structurally complex habitats assemblage were mostly omnivores, whereas the beach habitat assemblage included mainly piscivores and detritivores. Results from this study suggest that overall abundance of fishes in habitats within and surrounding Taraira Lake is highly variable among seasons, but species habitat affinity is maintained through seasons.

Neste estudo, investiguei mudanças na abundância e distribuição espacial de peixes de médio a grande porte (> $100 \mathrm{~mm}$ ) em um lago do baixo rio Apaporis, na Amazônia colombiana, durante três períodos hidrológicos (águas descendentes, baixas e ascendentes). No total foram coletadas 53 espécies, pertencentes a 13 famílias, em 6 hábitats: bosque inundado, canais, um arroio, grupos isolados de arbustos, praias e grandes rochas. A abundância, biomassa e riqueza de espécies foram maiores durante as águas ascendentes e menores durante as águas descendentes. Uma análise de correspondência (CA) mostrou que grupos de peixes se associaram a dois tipos básicos de hábitat. Um grupo de peixes se associou com hábitats com alta cobertura vegetal e complexidade estrutural (bosque inundado, canais, arroio e grupos isolados de arbustos) e um segundo grupo de peixes se associou com praias arenosas. Estas associações de espécies se mantiveram apesar da flutuação no nível da água. Espécies em hábitats estruturalmente complexos foram principalmente de hábitos omnívoros, enquanto que o grupo associado a praias incluiu principalmente piscívoros e detritívoros. Os resultados deste estudo sugerem que a abundância de peixes no lago Taraira e em hábitats adjacentes é variavel estacionalmente, porém a afinidade das espécies pelo hábitat se mantem através dos períodos hidrológicos.

Key words: Community ecology, Population abundance, Apaporis River, Habitat affinity.

\section{Introduction}

Seasonal floods in Amazonian floodplains, although large in scale, have a relatively predictable timing and occur gradually, allowing organisms to adjust accordingly (Junk et al., 1989; Junk, 1997). In contrast, unpredictable flash floods that frequently occur in temperate streams cause strong disturbances to aquatic communities (Junk et al., 1989; Poff \& Allan, 1995), and the process of recovery after disturbance is very dynamic and complex (Grossman et al., 1990). Predictable and lasting aquatic and terrestrial phases permit more efficient use of resources (Junk et al., 1997b). Nevertheless, the drastic

Department of Wildlife and Fisheries Sciences, Texas A\&M University, College Station, TX 77843-2258. scorrea@tamu.edu 
fluctuation of water level along the main stem Amazon River (i.e. between 7 to $13 \mathrm{~m}$ in most of the main tributaries) (Goulding, 1980) changes the landscape, impacting the ecological dynamics of fishes. With the rise of the water, different water bodies (e.g. lakes, rivers, lagoon channels, streams, and flooded forest) become interconnected creating a complex mosaic of habitats. The newly inundated system offers abundant food resources of allochthonous origin (e.g., terrestrial herbaceous plants, plant material from the flooded forest such as leaves, flowers, and fruits; and terrestrial invertebrates) (Junk et al., 1997b). Increased resource abundance and habitat connectivity during the flood season, and population reductions during the low- and rising-water seasons (caused by predation, stranding, and dissolved oxygen depletion among others) are some of the mechanisms underlying the maintenance of the high fish species diversity that characterizes the Amazon Basin (e.g., Goulding, 1980; LoweMcConnell, 1987; Goulding et al., 1996, Junk et al., 1997a).

Fish assemblage structure in tropical seasonal systems was suggested to be highly stochastic, with assemblages been restructured every new season without an apparent pattern of organization (e.g., Lowe-McConnell, 1979, 1987; Goulding et al., 1988; Junk et al., 1997a). However, more recent studies have seemingly found non-random associations of fishes in seasonal systems in which abiotic and biotic factors are influencing fish assemblage structure. Environmental variables, such as dissolved oxygen and hypoxia tolerance (Junk et al., 1983; Winemiller, 1996), depth and transparency (i.e. influencing predator abundances, Rodriguez \& Lewis, 1997), amount of nutrients and water chemistry (CoxFernandes, 1998; Saint-Paul et al., 2000; Petry et al., 2003), habitat complexity (Petry et al., 2003) and drainage area (CoxFernandes, 1998), have been suggested as predictors of fish assemblage structure in floodplain systems. Layman and Winemiller (2004) found direct evidence for the influence of predator abundance on medium-size prey fishes in beach communities of a lowland river in Venezuela during the low-water season. Arrington et al. (2005) found evidence for species interactions influencing fish assemblage structure mediated by dispersal dynamics in response to changing water levels in a floodplain river in the Venezuelan llanos.

Peer-reviewed literature on fish assemblage structure from the northwestern tributaries of the Amazon River Basin is limited except for the Ecuadorian Amazon (e.g. Ibarra \& Stewart, 1989; Galacatos et al., 1996; Stewart et al., 2002; Galacatos et al., 2004). The Upper Amazon (sensu Hubert \& Renno, 2006), which includes all rivers west of the Lower Madeira River, is characterized by high endemism and shares few species with other areas of the Amazon basin (Hubert \& Renno, 2006). In addition, the Caquetá and Putumayo rivers have a different species composition compared to other rivers within the Upper Amazon (Hubert and Renno, 2006). In particular, the ichthyofauna of the Apaporis River, a major tributary of the Caquetá River (about 1200 km long and 47,000 $\mathrm{km}^{2}$ drainage area) (PAT, 1997), is largely unexplored (Correa, 2003). The present study examines the effects of hydrological seasonality on assemblage structure and habitat affinity of medium- and large-sized fishes in habitats within and surrounding a large blackwater oxbow-lake of the Lower Apaporis River. The working hypothesis is that fish assemblages found in habitats in the oxbow-lake will not be conserved through the annual hydrological cycle, because of the changes in the structure of existing habitats and resource availability which are caused by the hydrological cycle. This study contributes to understanding of ecological relationships within relatively undisturbed fish communities, and will establish a base line for future ecological studies of the northwestern Amazon basin.

\section{Materials and Methods}

\section{Study Site}

Taraira is a large (approximately $22 \mathrm{~km}$ long), oligotrophic oxbow-lake of the lower Apaporis River, Colombian Amazon $\left(1^{\circ} 08^{\prime} 46.30^{\prime \prime} \mathrm{S}, 69^{\circ} 29^{\prime} 14.38^{\prime \prime} \mathrm{W}\right)$. It is located within the Guiana Shield, which is characterized by low nutrient whitesand soils of pre-Cambrian origin (Fig. 1; Domínguez, 1975). Taraira lake's blackwater contains low phytoplankton biomass (0.04 $\mathrm{mg} \mathrm{l}^{-1}$ chlorophyll $a$; PAT, 1997), and no aquatic macrophytes (Table 1). Annual precipitation is bimodal, with a mean of 3,832.5 mm rainfall per year ( $\mathrm{n}=11$ years; Defler, 1996). The hydrological cycle fluctuates $9 \mathrm{~m}$, with minimum levels from mid December to mid February and maximum levels from May to middle August. The lake has a diverse fish community in which characiforms, siluriforms and cichlids are the richest taxa (Correa, 2003). Species richness was estimated at 121 species (Correa, 2003). The lake is surrounded by primary rainforest (Defler, 1996), and hunting and fishing pressures are light.

\section{Data collection}

Seven habitats were recognized within and surrounding the lake: open-waters, lagoon channels, a stream, flooded

Table 1. Mean (and range) of environmental variables recorded during three seasons in Taraira Lake. Values estimated from biweekly measurements from August 1997 to April 1998. Significant differences among seasons (one-way ANOVA) are indicated as follow: ${ }^{*} P<0.05$, ${ }^{* *} P<0.01$.

\begin{tabular}{lccc}
\hline Variable & Falling water & Low water & Rising water \\
\hline $\mathrm{pH}$ & $5.4(5.3-5.5)$ & $5.6(5.5-5.7)$ & $5.6(5.5-5.7)$ \\
Dissolved $\mathrm{O}_{2}\left(\mathrm{mg} \mathrm{l}^{-1}\right)$ & $6.6(4.3-8.8)$ & $8.5(8.4-8.6)$ & $6.8(5.7-7.7)$ \\
$\mathrm{CO}_{2}\left(\mathrm{mg} \mathrm{l}^{-1}\right)$ & $10.6(5.8-19.2)$ & $5.0(4.8-5.2)$ & $8.6(7.4-10.4)$ \\
${\mathrm{Chloride}\left(\mathrm{mg} \mathrm{l}^{-1}\right)}^{14.5(11.0-18.0)}$ & $17.0(8.0-26.0)$ & $11.0(8.0-13.0)$ \\
Ammonia $\left(\mathrm{mg} \mathrm{l}^{-1}\right)$ & $0.5(0.5-0.6)$ & $0.5(0.4-0.5)$ & $0.23(0-0.4)$ \\
Depth (m) & $5.0(3.2-7.7)$ & $1.3(0.5-3.0)^{* *}$ & $3.3(2.2-6.5)$ \\
Temperature ( $\left.{ }^{\circ} \mathrm{C}\right)$ & $27.7(25.0-37.1)$ & $28.5(26.5-32.0)$ & $28.5(24.4-31.7)$ \\
Secchi transparency & & 70.0 & 123.8 \\
$(\mathrm{~cm})$ &. & $(27.0-135.0)^{*}$ & $(85.0-170.0)$ \\
\hline
\end{tabular}




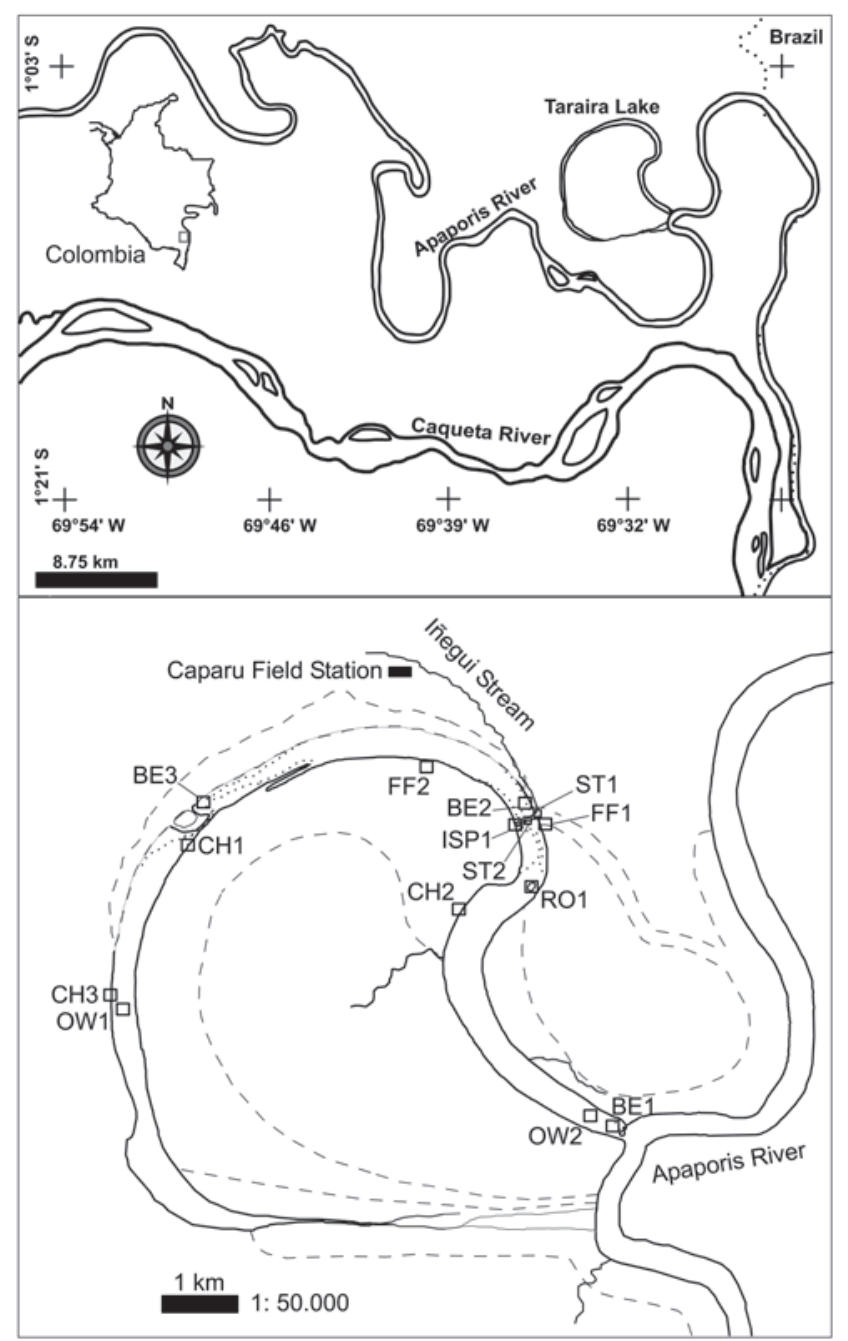

Fig. 1. Location of the study area and sampling sites. In the lower panel, broken lines represent the extension of the flooded forest (igapó). Dotted lines represent muddy beaches (in the low-water season). Sampling sites are represented by squares. Habitat abbreviations follow Table 2. Map of the Taraira Lake was adapted from Botello (2000).

forests, muddy beaches, isolated shrub patches, and an aggregation of partially submerged large rocks. Open-waters correspond to the pelagic zone of the lake, which is approximately $200 \mathrm{~m}$ at the wider point. Water level ranges from $4 \mathrm{~m}$ at the edge of the flooded forest, to $17 \mathrm{~m}$ in the middle of the lake, during the flooding season. As the water recedes, the body of the lake shrinks in some areas to form channels $10 \mathrm{~m}$ wide and 4 to $5 \mathrm{~m}$ in depth at the peak of the dry season. Multiple lagoon channels, fed by small rainforest clearwater streams, flow into the lake. The majority of these channels have water flow throughout the year. During the flooded season, the mouth of the channel is up to $80 \mathrm{~m}$ wide and $8 \mathrm{~m}$ in depth. Farther upstream however, the channel shrinks and disappears inside the flooded forest. A large, clearwater stream, originated in the Serranía del Taraira flows into the north portion of the lake (Fig. 1). This cool, potentially turbid, fast flowing stream has continuous water flow through the year, which is highly dependent on local rainfall. A mature Igapó flooded forest growing over sandy soils surrounds the lake. This forest remains flooded 5 Mo of the year. Numerous muddy beaches are formed as the water recedes which are rapidly colonized by grasses. The areas that remain flooded are shallow (05. to $1 \mathrm{~m}$ depth) and the water reaches high temperature around noon. Isolated shrub patches are mainly found in two areas where the lake narrows (Fig. 1). These patches are dominated by one species in the Myrtaceae family, which produces fruit that are consumed by palometas (serrasamids). One of these shrub patches remains flooded throughout the year; it serves as a refuge for large numbers of fishes during the dry- and rising-water seasons. There is an aggregation of partially submerged large rocks on the eastern portion of the lake. The rocks are almost completely covered by water during the peak of the flood and become increasable exposed as the water recedes.

Fifteen sampling sites representing the different habitats present in the lake where selected. Sampling was conducted during falling, low- and rising-water seasons (August-September 1997, late December-mid February 1998, and late February-early April 1998, respectively). Because of the strong seasonality in the water level, some habitats where unavailable for sampling during certain seasons (see Table 2). Standardized samples were collected using a large monofilament gill net ( $15 \mathrm{~cm}$ stretch mesh size, $60 \mathrm{~m}$ x $2 \mathrm{~m}$ ) that was deployed for 4-6 $\mathrm{h}$ at each sampling site. The net was set close to the surface in all habitats and perpendicular to the shore in openwater, beach, and flooded forest habitats. In open water and beach habitats, the net was anchored to wooden sticks to help keep it open. In channels and in the stream, the net was deployed perpendicular to the flow of the water. At the shrub patches and the aggregation of rocks, the net was deployed around the habitat. In all cases, all efforts were made to ensure that only one habitat was sampled during each sampling period. Additional sampling was conducted using a short monofilament gill net ( $8 \mathrm{~cm}$ stretch mesh size, $20 \mathrm{~m}$ x $2 \mathrm{~m}$ ), cast

Table 2. Number of sampling sites per habitat during each hydrological season. Habitat abbreviations are: OW - Open Waters; FF - Flooded Forests; CH - Lagoon channels; ST Stream; ISP - Isolated Shrub Patches; BE - Beaches; RO Rocks.

\begin{tabular}{lccccccc}
\hline Habitats/ Seasons & OW & FF & CH & ST & ISP & BE & RO \\
\hline Falling Water & 2 & 2 & 3 & 2 & 1 & 0 & 0 \\
Low Water & 2 & 0 & 3 & 2 & 1 & 3 & 1 \\
Rising Water & 2 & 2 & 3 & 2 & 1 & 3 & 1 \\
\hline
\end{tabular}


net, hook and line, hanging hooks, harpoon, and arrow. The large gill net was also used to make enclosures on beaches during the low- and rising-water seasons. Sampling activity was rotated among sites in a daily bases and fishing was conducted during the day time in all habitats.

Capture fishes were removed from the large gill net each hour, and species identity, number of individuals per species, standard length, weight, and habitat type were recorded. Fishes caught with other fishing gear were also recorded at this time. Specimens were euthanized by anesthetic overdose in a $0.4 \mathrm{mg} \mathrm{l}^{-1}$ solution of 2-phenoxyethanol, fixed in $10 \%$ formalin, and later preserved in ethanol $70 \%$. Voucher specimens for almost all species were deposited in fish collections of the Instituto de Ciencias Naturales-Museo de Historia Natural (ICN-MHN) of the Universidad Nacional, and of the Universidad del Valle; both in Colombia.

At each habitat, daily measurements of water depth, transparency (measure by a Secchi disk) and temperature were recorded (transparency was not recorded during the falling water season). In order to monitor changes in water chemistry across seasons, a biweekly series of measurements were conducted for dissolved $\mathrm{O}_{2}$ (Winkler's method), $\mathrm{CO}_{2}$ (sodium hydroxide method), chloride (mercury nitrate method), ammonium, and $\mathrm{pH}$, using a LaMotte water testing kit (Table 1). These measurements were conducted in the main channel of the lake, at the same location, for all seasons.

\section{Data analysis}

No fishes were captured in the deep open-water habitat; therefore this habitat was not included in the data analysis. Overall abundance, biomass, and species richness, as well as the relative abundance of individual species (Table 3), were calculated based on the total of fishes caught with all fishing gear. Seasonal comparison of abundance, biomass, species richness, diversity, and species composition across habitats were based only on fishes collected with the large gill net. Simpson's diversity index, ranging from 0 to 1 , calculates the probability that two individuals extracted at random from a sample belong to different species (Krebs, 1999). The Simpson's diversity index was calculated based on species abundance for each habitat (Ecological Methodology software; Kenney \& Krebs, 2000).

Daily measured environmental variables (i.e., depth, temperature, and water transparency) were analyzed using oneway ANOVA in order to test for differences among seasons, and among habitats within seasons. Pearson's correlation analysis was used to explore possible correlations among these environmental variables.

Differences in species composition among habitats were evaluated using a multi-response permutation procedure (MRPP; PC-ORD software; McCune \& Mefford, 1999) on a matrix of species abundance per site. MRPP is a nonparametric multivariate analysis that tests for differences between $a$ priori defined groups (e.g. habitat; Mielke, 1984). In this case, MRPP was used to test the null hypothesis of no difference in species composition between habitats. For the analysis, the samples of a habitat over the different season were coded as a group. Thus the MRPP tested if the homogeneity within the group (i.e. habitat) was higher than expected by chance, which means that the two or three temporal samples of a habitat are more similar to each other, than to samples of other habitats at the same season. Before this analysis, two species that were identified as outliers were deleted yielding a new matrix of six habitats and 29 species. Abundance data were $\log$ transformed $(\log x+1)$ to reduce the influence of highly abundant species (e.g., Cichla monoculus and Serrasalmus rhombeus) and uncommon ones (McCune \& Grace, 2002). Patterns of assemblage structure were further examined with correspondence analysis (CA; PC-ORD software, McCune \& Mefford, 1999), a multivariate technique for indirect ordination (Gauch \& Whittaker, 1981) that simultaneously ordinates samples and species. Despite the fact that CA ordination produces an arch effect (Hill \& Gauch, 1980), it was used instead of detrended correspondence analysis (DCA), an alternative ordination method that eliminates the arch effect, because DCA produces inconsistent results which are the product of detrending and rescaling procedures (Minchin, 1987; Legendre and Legendre, 1998), and the arbitrary homogenization of scores (Ter Braak, 1986). Rare species were down-weighted, and abundance was not log transformed since CA standardizes data by weighting samples by their totals (i.e. chi transformation).

\section{Results}

Over the three survey seasons, 669 individuals of 53 species from 13 families, and six orders, were collected. Over $50 \%$ of all captured individuals was accounted by the peacock bass (C. monoculus), piraña (S. rhombeus), and a doradid catfish (Oxydoras niger) (Table 3). Only the first two species were caught in all of the habitats, and either one or the other was the most abundant species in each habitat, except in beaches were $O$. niger was by far the most abundant species (Table 3). Overall abundance, biomass, and species richness were lower during the falling-water season (177 individuals, $74.2 \mathrm{~kg}$, and 21 species), and higher during the rising-water season (256 individuals, $152.6 \mathrm{~kg}$, and 44 species).

Half of all specimens were only captured using the large gill net (336 individuals), and $55 \%$ of these fishes were characids. Effectiveness of the other fishing gear was variable among taxa. For instance, $79 \%$ of fishes caught with the harpoon were pimelodid catfishes, and $40 \%$ of fishes caught with the cast net were prochilodontids. Most of the fishes caught with these two gears were taken at beaches. The hook and line method was more effective capturing characids (54\%), and the small gill net was most efficient for capturing cichlids (56\%). 


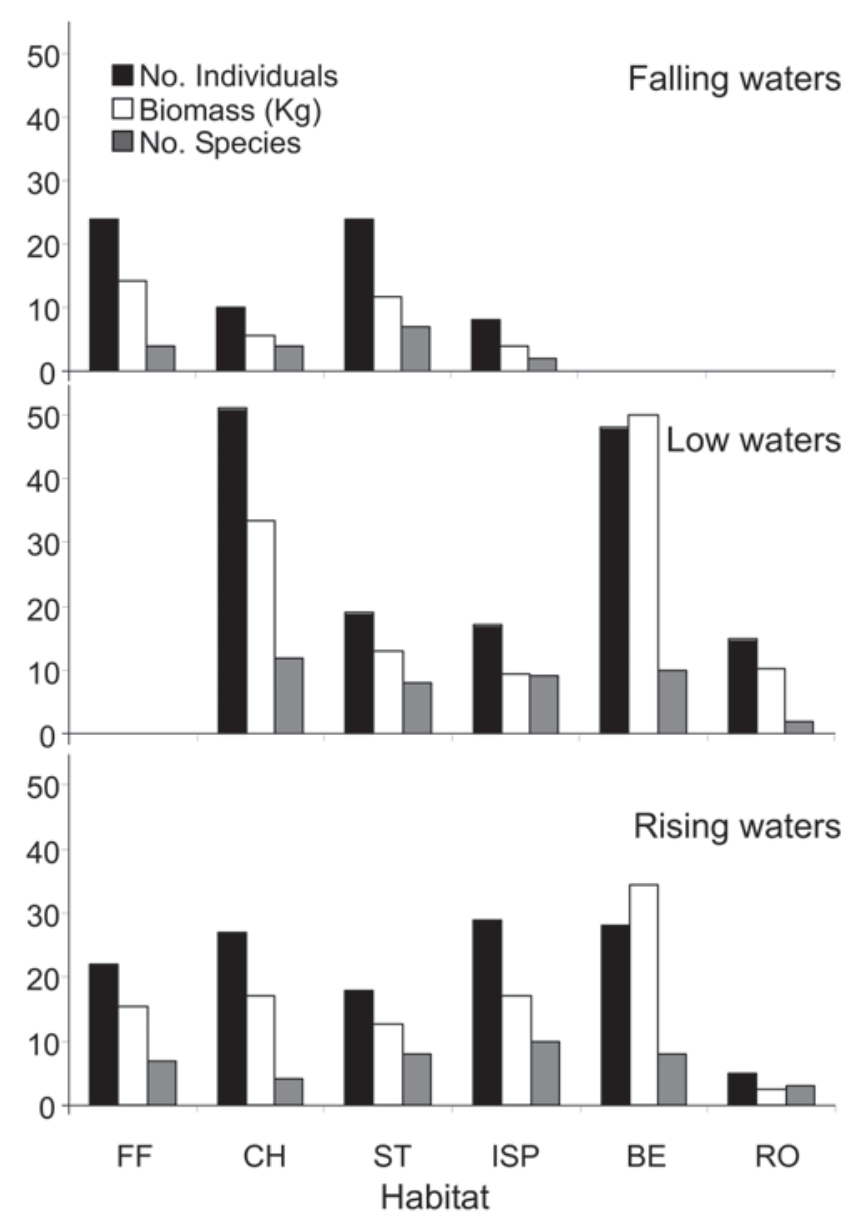

Fig. 2. Comparison of total abundance, biomass, and species richness among habitats, at three seasons in the Taraira Lake. Richness was expressed as total number of species collected in a habitat. Habitat names correspond to those in Table 2. Values represent fishes collected with the large gill net only.

Abundance, biomass and species richness seasonally fluctuated across habitats. During the falling-water season, flooded forests and the stream held the highest fish abundance, biomass and species richness. During the low-water season, lagoon channels held the highest fish abundance and species richness, but the beaches held higher biomass. During the rising-water season, the highest biomass was at beaches, but recently inundated shrub patches held the highest abundance and species richness (Fig. 2). Species diversity (calculated with Simpson's Index) was higher in the stream during all three seasons. The lowest diversity was found in patches of shrubs during the falling-water season, in the rocks during the low-water season, and in lagoon channels during the rising-water season.

Among environmental variables, only water level (Tukey, $P<0.01$ ) and transparency (T-test, $t=4.06, P<0.05$ ) showed significant fluctuation among seasons (Table 1 ). Water level and transparency were positively correlated (Pearson Corre-

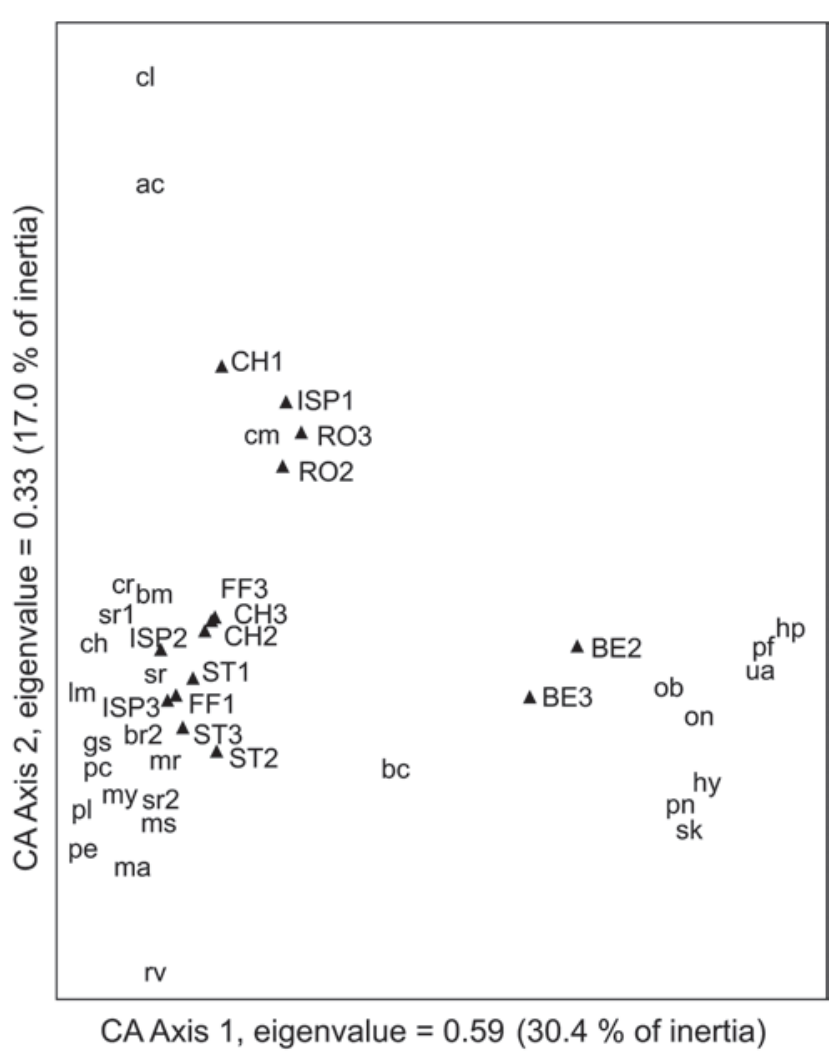

Fig. 3. CA ordination of six habitats across three seasons based on fish abundance of fishes collected with the large gill net only. Triangles represent habitats and crosses represent species. Habitat names correspond to those in Table 2. Numbers following habitat abbreviations correspond to seasons (i.e., 1: Falling water, 2: Low water, 3: Rising water). Species codes are given in Table 3.

lation, $r=0.86, P<0.05$ ), therefore I only tested for water level differences among habitats during each season. During the falling-water season, flooded forests had lower water level than both lagoon channels and the stream (Tukey, $P<0.01$, and $P<0.001$, respectively). Beaches had significantly lower water level than lagoon channels during the low-water season (Tukey, $P<0.05$ ), and than rocks during the rising-water season (Tukey, $P<0.01$ ).

Assemblage composition was significantly different among habitats (MRPP, $A=0.28, P<0.01$ ). This pattern was also revealed by the $C A$ ordination in which certain habitats were clustered together regardless of the season in which they were sampled (Fig. 3). The first CA axis (explaining 30.4\% of the total variance) separated an assemblage of eight species associated with beaches. Based on CA species scores, this assemblage was largely influenced by the abundance of Hemisorubim platyrhynchos, Pseudoplatystoma fasciatum, Hydrolycus scomberoides, Uaru amphiacanthoides, Prochilodus nigricans, and Semaprochilodus cf. kneri which were only caught in this habitat; and by the abundance of 
Table 3. Relative abundance (percentage of total number of individuals, $n=669$ ), of 53 species captured in six habitats in Taraira Lake, during three seasons. Habitat abbreviations follow Table 2. Codes given for species included in CA. Other abbreviations: LN - long gill net; $\mathrm{SN}$ - short gill net; $\mathrm{NE}$ - net enclosure; $\mathrm{CN}$ - cast net; $\mathrm{H}$ - hook and line; $\mathrm{HH}$ - hanging hook; AR - arrow; HA - harpoon. Collection's catalog numbers are provided by Correa (2003).

\begin{tabular}{|c|c|c|c|c|c|c|c|c|c|c|c|c|c|c|c|c|c|c|}
\hline \multirow[b]{2}{*}{ Species } & \multirow{2}{*}{$\begin{array}{l}\text { Spp. } \\
\text { code }\end{array}$} & \multirow[b]{2}{*}{ Fishing Gear } & \multicolumn{4}{|c|}{ Falling season } & \multicolumn{5}{|c|}{ Low season } & \multicolumn{6}{|c|}{ Rising season } & \multirow[b]{2}{*}{$\%$ of Total } \\
\hline & & & FF & $\mathrm{CH}$ & ST & ISP & $\mathrm{CH}$ & ST & ISP & $\mathrm{BE}$ & $\mathrm{RO}$ & $\mathrm{FF}$ & $\mathrm{CH}$ & ST & ISP & $\mathrm{BE}$ & $\mathrm{RO}$ & \\
\hline Cichla monoculus & $\mathrm{cm}$ & LN,SN,NE,H & 3.0 & 4.3 & 0.6 & 1.8 & 1.8 & 0.1 & 0.1 & 1.8 & 3.0 & 2.4 & 1.3 & 0.4 & 0.4 & 0.9 & 1.2 & 23.3 \\
\hline Serrasalmus rhombeus & $\mathrm{sr}$ & LN,SN,H & 3.1 & 0.4 & 1.6 & 0.6 & 4.2 & 1.2 & 1.3 & 0.1 & 0.3 & 1.3 & 2.8 & 1.3 & 2.1 & 0.7 & 0.1 & 21.5 \\
\hline Oxydoras niger & on & LN,SN,CN & 0.0 & 0.0 & 0.0 & 0.0 & 0.1 & 0.1 & 0.0 & 3.4 & 0.0 & 0.0 & 0.0 & 0.0 & 0.0 & 2.1 & 0.0 & 5.8 \\
\hline Brycon melanopterus & & LN,SN,H,HH & 0.4 & 0.0 & 0.0 & 0.0 & 0.6 & 1.2 & 0.0 & 0.0 & 0.0 & 0.9 & 0.9 & 0.4 & 0.0 & 0.0 & 0.4 & 4.9 \\
\hline Myleus rubripinnis & $\mathrm{mr}$ & LN,SN,H & 0.9 & 0.0 & 1.2 & 0.0 & 0.0 & 0.0 & 0.0 & 0.0 & 0.0 & 0.7 & 0.0 & 0.4 & 0.1 & 0.1 & 0.0 & 3.6 \\
\hline Triportheus elongatus & & $\mathrm{SN}, \mathrm{H}, \mathrm{HH}$ & 0.4 & 0.0 & 0.0 & 0.6 & 0.0 & 0.0 & 0.0 & 0.0 & 0.0 & 0.4 & 0.3 & 0.9 & 0.3 & 0.0 & 0.0 & 3.0 \\
\hline Serrasalmus sp.2 & sr2 & LN,NE,H & 0.3 & 0.0 & 0.7 & 0.0 & 0.4 & 0.3 & 0.0 & 0.4 & 0.0 & 0.0 & 0.0 & 0.3 & 0.1 & 0.0 & 0.0 & 2.7 \\
\hline Pimelodus blochii & & $\mathrm{H}, \mathrm{HH}, \mathrm{HA}$ & 0.0 & 0.0 & 0.0 & 0.0 & 0.0 & 1.0 & 0.0 & 0.0 & 0.0 & 0.0 & 0.0 & 1.2 & 0.0 & 0.0 & 0.0 & 2.2 \\
\hline Semaprochilodus cf. kneri & sk & LN,SN,CN & 0.3 & 0.0 & 0.1 & 0.0 & 0.0 & 0.0 & 0.0 & 1.5 & 0.0 & 0.0 & 0.0 & 0.0 & 0.0 & 0.1 & 0.0 & 2.1 \\
\hline Serrasalmus elongatus & & $\mathrm{SN}, \mathrm{H}$ & 0.0 & 1.2 & 0.1 & 0.0 & 0.1 & 0.0 & 0.0 & 0.0 & 0.0 & 0.1 & 0.1 & 0.0 & 0.1 & 0.0 & 0.0 & 1.9 \\
\hline Crenicichla lenticulata & $\mathrm{cl}$ & LN,SN,H,AR & 0.0 & 0.6 & 0.0 & 0.0 & 0.3 & 0.3 & 0.0 & 0.0 & 0.3 & 0.1 & 0.0 & 0.0 & 0.0 & 0.0 & 0.0 & 1.6 \\
\hline Satanoperca jurupari & & LN,SN,CN & 0.3 & 0.0 & 0.0 & 0.0 & 0.1 & 0.0 & 0.1 & 0.9 & 0.0 & 0.0 & 0.1 & 0.0 & 0.0 & 0.0 & 0.0 & 1.6 \\
\hline Astronotus ocellatus & & $\mathrm{H}$ & 0.0 & 0.0 & 0.0 & 0.0 & 0.0 & 0.1 & 0.0 & 0.0 & 0.9 & 0.1 & 0.0 & 0.0 & 0.0 & 0.0 & 0.4 & 1.6 \\
\hline Boulengerella cf. cuvieri & bc & LN,SN,CN & 0.0 & 0.0 & 0.4 & 0.0 & 0.0 & 0.3 & 0.0 & 0.4 & 0.0 & 0.0 & 0.1 & 0.0 & 0.0 & 0.1 & 0.0 & 1.5 \\
\hline Hoplias malabaricus & & C & 0.0 & 0.0 & 0.0 & 0.0 & 0.4 & 0.0 & 0.0 & 0.7 & 0.0 & 0.0 & 0.0 & 0.0 & 0.0 & 0.1 & 0.0 & 1.3 \\
\hline Osteoglossum bicirrhosum & ob & LN,SN & 0.0 & 0.0 & 0.0 & 0.0 & 0.0 & 0.0 & 0.0 & 0.9 & 0.0 & 0.1 & 0.0 & 0.1 & 0.0 & 0.1 & 0.0 & 1.3 \\
\hline Pseudoplaty & $\mathrm{pf}$ & LN,NE,HA & 0.0 & 0.0 & 0.0 & 0.0 & 0 & 0.0 & 0.0 & 0.4 & 0.0 & 0.0 & 0.0 & 0.0 & 0.0 & 0.9 & 0.0 & 1.3 \\
\hline prhynch & ac & LN, & 0.0 & 0.6 & 0.3 & 0.1 & 0.0 & 0.0 & 0.1 & 0.0 & 0.0 & 0.0 & 0.0 & 0.0 & 0.0 & 0.0 & 0.0 & 1.2 \\
\hline Geophagus surinamensis & gs & LN,SN,NE,CN & 0.0 & 0.1 & 0.0 & 0.0 & 0.1 & 0.1 & 0.1 & 0.6 & 0.0 & 0.0 & 0.0 & 0.0 & 0.0 & 0.0 & 0.0 & 1.2 \\
\hline Myleus schomburgkii & $\mathrm{ms}$ & LN & 0.0 & 0.0 & 0.0 & 0.0 & 0.1 & 0.4 & 0.1 & 0.0 & 0.0 & 0.1 & 0.0 & 0.0 & 0.3 & 0.0 & 0.0 & 1.2 \\
\hline Brycon sp.2 & br2 & LN,SN,H & 0.1 & 0.1 & 0.0 & 0.0 & 0.4 & 0.1 & 0.0 & 0.0 & 0.0 & 0.0 & 0.0 & 0.1 & 0.0 & 0.0 & 0.0 & 1.0 \\
\hline Hydrolycus scomberoides & hy & LN,SN & 0.3 & 0.0 & 0.1 & 0.1 & 0.0 & 0.0 & 0.0 & 0.0 & 0.0 & 0.0 & 0.0 & 0.0 & 0.0 & 0.4 & 0.0 & 1.0 \\
\hline Myle & my & LN & 0.0 & 0.0 & 0.0 & 0.0 & 0.0 & 0.0 & 0.0 & 0.0 & 0.0 & 0.0 & 0.1 & 0.3 & 0.6 & 0.0 & 0.0 & 1.0 \\
\hline hla lugubris & $\mathrm{cr}$ & LN,H & 0.0 & 0.0 & 0.0 & 0.0 & 0.1 & 0.0 & 0.0 & 0.0 & 0.4 & 0.0 & 0.1 & 0.1 & 0.0 & 0.0 & 0.0 & 0.9 \\
\hline Potal & & LN & 0.0 & 0.1 & 0.1 & 0.0 & 0.0 & 0.0 & 0.0 & 0.0 & 0.0 & 0.0 & 0.0 & 0.4 & 0.1 & 0.0 & 0.0 & 0.9 \\
\hline Brycon sp.1 & & $\mathrm{H}, \mathrm{HH}$ & 0.0 & 0.0 & 0.0 & 0.0 & 0.0 & 0.0 & 0.0 & 0.0 & 0.0 & 0.0 & 0.3 & 0.1 & 0.1 & 0.0 & 0.1 & 0.7 \\
\hline Chalceus macr & ch & $\mathrm{LN}, \mathrm{H}$ & 0.0 & 0.0 & 0.0 & 0.0 & 0.0 & 0.0 & 0.1 & 0.0 & 0.0 & 0.3 & 0.3 & 0.0 & 0.0 & 0.0 & 0.0 & 0.7 \\
\hline Leiarius marm & $\operatorname{lm}$ & LN & 0.0 & 0.0 & 0.0 & 0.0 & 0 & 0.0 & 0.1 & 0.0 & 0.0 & 0 & 0.0 & 0.0 & 0.1 & 0.4 & 0.0 & 0.7 \\
\hline Lepo & & $\mathrm{Cl}$ & 0.0 & 0.0 & 0.0 & 0.1 & 0 & 0.0 & 0.0 & 0.0 & 0.0 & .0 & 0.1 & 0.4 & 0.0 & 0.0 & 0.0 & 0.7 \\
\hline ulatus & & $\mathrm{H}$ & 0.0 & 0.0 & 0.0 & 0. & .0 & 0.0 & 0.0 & 0.0 & 0.0 & 0.0 & 0.0 & 0.7 & 0.0 & 0.0 & 0.0 & 0.7 \\
\hline Myloplus a & ma & LN & 0.0 & 0.0 & 0.0 & 0.0 & 0.0 & 0.1 & 0.0 & 0.0 & 0.0 & 0.1 & 0.0 & 0.3 & 0.0 & 0.0 & 0.0 & 0.6 \\
\hline Serrasalmus eigenmani & & LN.H & 0.0 & 0.0 & 0.1 & 0.0 & 0.0 & 0.1 & 0.0 & 0.0 & 0.0 & 0.0 & 0.1 & 0.0 & 0.1 & 0.0 & 0.0 & 0.6 \\
\hline Mesonauta festivum & & $\mathrm{H}$ & 0.0 & 0.0 & 0.0 & 0.0 & 0.4 & 0.0 & 0.0 & 0.0 & 0.0 & 0.0 & 0.0 & 0.0 & 0.0 & 0.0 & 0.0 & 0.4 \\
\hline Rhaphiodon vulpinus & rv & LN,SN & 0.0 & 0.0 & 0.1 & 0.0 & 0.0 & 0.1 & 0.0 & 0.0 & 0.0 & 0.0 & 0.0 & 0.0 & 0.1 & 0.0 & 0.0 & 0.4 \\
\hline Serrasalmus sp.1 & sr1 & LN,SN & 0.1 & 0.0 & 0.0 & 0.0 & 0.0 & 0.0 & 0.0 & 0.0 & 0.0 & 0.0 & 0.1 & 0.0 & 0.1 & 0.0 & 0.0 & 0.4 \\
\hline Colossoma macropomun & & HA & 0.0 & 0.0 & 0.0 & 0.0 & 0.0 & 0.0 & 0.0 & 0.0 & 0.0 & 0.0 & 0.0 & 0.0 & 0.0 & 0.3 & 0.0 & 0.3 \\
\hline Heros & & $\mathrm{H}$ & 0.0 & 0.0 & 0.0 & 0.0 & 0.0 & 0.0 & 0.0 & 0.0 & 0.0 & 0.0 & 0.0 & 0.0 & 0.0 & 0.0 & 0.3 & 0.3 \\
\hline asciatum & & $\mathrm{SN}, \mathrm{H}$ & 0.0 & 0.0 & 0.0 & 0.0 & 0.0 & 0.0 & 0.0 & 0.0 & 0.0 & 0.0 & 0.0 & 0.0 & 0.0 & 0.1 & 0.1 & 0.3 \\
\hline Potamotrygon cf. schoederi & ps & $\mathrm{H}, \mathrm{AR}$ & 0.0 & 0.0 & 0.0 & 0.0 & 0.1 & 0.1 & 0.0 & 0.0 & 0.0 & 0.0 & 0.0 & 0.0 & 0.0 & 0.0 & 0.0 & 0.3 \\
\hline Semaprochilodus cf. taeniurus & & SN,AR & 0.0 & 0.0 & 0.0 & 0.0 & 0.0 & 0.0 & 0.0 & 0.1 & 0.0 & 0.0 & 0.1 & 0.0 & 0.0 & 0.0 & 0.0 & 0.3 \\
\hline Uaru amphiacanthoides & ua & LN & 0.0 & 0.0 & 0.0 & 0.0 & 0.0 & 0.0 & 0.0 & 0.3 & 0.0 & 0.0 & 0.0 & 0.0 & 0.0 & 0.0 & 0.0 & 0.3 \\
\hline Bouler & bm & $\mathrm{L}$ & 0.0 & 0.0 & 0.0 & 0.0 & 0.1 & 0.0 & 0.0 & 0.0 & 0.0 & 0.0 & 0.0 & 0.0 & 0.0 & 0.0 & 0.0 & 0.1 \\
\hline Hemisorubim platyrhynchos & hp & LN & 0.0 & 0.0 & 0.0 & 0.0 & 0.0 & 0.0 & 0.0 & 0.1 & 0.0 & 0.0 & 0.0 & 0.0 & 0.0 & 0.0 & 0.0 & 0.1 \\
\hline Hypophthalmus edentatus & & SN & 0.0 & 0.0 & 0.0 & 0.0 & 0.0 & 0.0 & 0.0 & 0.0 & 0.0 & 0.0 & 0.0 & 0.1 & 0.0 & 0.0 & 0.0 & 0.1 \\
\hline Leiarius pictus & & $\mathrm{H}$ & 0.0 & 0.0 & 0.0 & 0.0 & 0.0 & 0.0 & 0.0 & 0.0 & 0.0 & 0.0 & 0.0 & 0.0 & 0.0 & 0.0 & 0.1 & 0.1 \\
\hline Leporinus friderici & & $\mathrm{H}$ & 0.0 & 0.0 & 0.0 & 0.0 & 0.0 & 0.1 & 0.0 & 0.0 & 0.0 & 0.0 & 0.0 & 0.0 & 0.0 & 0.0 & 0.0 & 0.1 \\
\hline Pellona castelneana & $\mathrm{pc}$ & LN & 0.0 & 0.0 & 0.1 & 0.0 & 0.0 & 0.0 & 0.0 & 0.0 & 0.0 & 0.0 & 0.0 & 0.0 & 0.0 & 0.0 & 0.0 & 0.1 \\
\hline Plagioscion squamosissimus & $\mathrm{pl}$ & LN & 0.0 & 0.0 & 0.0 & 0.0 & 0.0 & 0.0 & 0.0 & 0.0 & 0.0 & 0.0 & 0.0 & 0.0 & 0.1 & 0.0 & 0.0 & 0.1 \\
\hline Prochilodus nigricans & $\mathrm{pn}$ & LN & 0.0 & 0.0 & 0.0 & 0.0 & 0.0 & 0.0 & 0.0 & 0.0 & 0.0 & 0.0 & 0.0 & 0.0 & 0.0 & 0.1 & 0.0 & 0.1 \\
\hline Psectrogaster sp. & pe & LN & 0.0 & 0.0 & 0.0 & 0.0 & 0.0 & 0.0 & 0.0 & 0.0 & 0.0 & 0.0 & 0.0 & 0.0 & 0.1 & 0.0 & 0.0 & 0.1 \\
\hline Pseudoplatystoma tigrinum & & HA & 0.0 & 0.0 & 0.0 & 0.0 & 0.0 & 0.0 & 0.0 & 0.0 & 0.0 & 0.0 & 0.0 & 0.0 & 0.0 & 0.1 & 0.0 & 0.1 \\
\hline Cynodon gibbus & & LN & 0.0 & 0.0 & 0.0 & 0.0 & 0.0 & 0.0 & 0.0 & 0.0 & 0.0 & 0.0 & 0.0 & 0.0 & 0.1 & 0.0 & 0.0 & 0.1 \\
\hline Triportheus pictus & & $\mathrm{H}$ & 0.0 & 0.0 & 0.0 & 0.0 & 0.0 & 0.0 & 0.0 & 0.0 & 0.0 & 0.0 & 0.0 & 0.1 & 0.0 & 0.0 & 0.0 & 0.1 \\
\hline
\end{tabular}

Osteoglossum bicirrossum and $O$. niger, the dominant species. The second CA axis (explaining $17 \%$ of the total variance) separated 17 species associated with a group of habitats consisting of the stream during all three seasons, flooded forest during falling- and rising-water seasons, and lagoon channels and isolated shrub patches during low- and risingwater seasons (Fig. 3). The separation of this cluster was mainly influenced by the abundances of 1) Psectrogaster sp., Plagioscion squamosissimus, Leiarius marmoratus, and Chalceus macrolepidotus, only present in isolated shrub patches; 2) Rhaphiodon vulpinus only present in the stream; and 3) few species, such as Myloplus asterias, Myleus schomburgkii, M. rubripinnis, Myleus sp., and Serrasalmus sp. 2, that occurred in multiple habitats (Table 3). Rocks dur- 
ing low- and rising-water seasons were clustered together with lagoon channels and isolated shrub patches during the falling-water season, and the abundance of $C$. monoculus influenced clustering of these habitats.

\section{Discussion}

The large magnitude of water level fluctuation in Amazon floodplains causes major changes in the landscape that directly influence key resources for fishes (e.g. food and shelter). Thus, water level changes induce dispersal and migratory behaviors that are reflected in seasonal shifts in local abundance and species richness. During the transition to the low-water season, many species leave the floodplain and move into the main river channel for refuge or to initiate migration for reproduction (Goulding, 1980, Lowe-McConnell, 1987; Barthem \& Goulding, 1997). However, many other fishes stay in floodplain lakes or undergo local migrations into affluent streams and lagoon channels. I observed several sábalos (Brycon melanopterus) migrating up stream at the end of the falling-water season and moving back into the main lake during the early rising-water season. At the beginning of the rising-water season, water level began to change, with increments of 0.5 to $1 \mathrm{~m}$ during the first days of the season. Fishes that were confined to reduced flooded areas during the low-water season moved to the new flooded areas where food presumably became more abundant. For example, beaches that were exposed during the low-water season, were colonized by terrestrial grasses, and later became flooded, representing a new source of food for a variety of fish. Small fishes seem to be attracted to this habitat by the abundance of both aquatic and terrestrial insects, and these small fishes consequently attracted piscivores, such as $C$. monoculus, Boulengerella cf. cuvieri, Cynodon gibbus, Rhaphiodon vulpinus, and $H$. scomberoides. Some of them were large fishes that significantly contributed to the high biomass observed at beaches during the rising-water season. Grasses also attracted herbivorous species. I caught two large individuals of gamitana (Colossoma macropomum) with stomachs full of grasses. This species is a frugivore during the adult stage (Goulding 1980, Araujo-Lima \& Goulding 1997). However, during the low-water season the availability of fruits is low (Goulding 1980), and the individuals that do not migrate metabolize fat stores accumulated during the previous flood (Junk, 1985). Thus, during the rising-water season, these flooded grasses may be an alternative food resource when fruits are unavailable. Other fish species that left the lake at the beginning of the low-water season may have return during the rising-water season, thus contributing to an increase in overall species richness.

Despite marked hydrologic seasonality, the structure of fish assemblages in Taraira Lake was consistent through time. Two main assemblages were identified in Taraira Lake, a large assemblage of species associated with lagoon channels, stream, isolated shrub patches and flooded forest habitats; and a second assemblage of species associated with muddy beaches. Non-random associations of fish species have seemingly been found in other seasonal system, influenced by characteristics of the habitat and by interspecific interactions (Rodriguez \& Lewis, 1997; Petry et al., 2003; Arrington et al. 2005).

The first and largest assemblage was composed by fishes with diverse diets (i.e., omnivores, piscivores, insectivores, frugivores and scale eaters). Diet was inferred from stomach contents and from the literature (e.g. Goulding, 1980; Soares et al., 1986; Goulding et al., 1988). Lagoon channels, stream, isolated shrub patches and flooded forest are habitats characterized by high vegetation cover which contributes allochthonous resources to the system (e.g. leaves, flowers, fruits, and terrestrial invertebrates). These resources are extremely valuable for fishes especially in blackwater systems like Taraira Lake. Primary productivity in this kind of water is extremely low, and this water cannot support the extensive floating meadows characteristic of whitewater systems (Goulding, 1980; Junk, 1997). In Taraira Lake, floating meadows are completely absent and primary productivity is very low (PAT, 1997). Fruits are very important resources for a great variety of fishes. Frugivory in South America have evolved as an important trophic guild in fish communities, and numerous species have been documented feeding on fruit material that seasonally falls into the water (Correa et al., 2007). Thus, vegetation cover could very likely be a good predictor of the fish diversity that a habitat could support. However, a detailed study of resource partitioning would be necessary to better explain mechanisms of species coexistence among highly vegetated habitats.

Structural complexity of the habitat influences species richness and species coexistence (Werner \& Hall, 1976; Huston, 1994). Habitats in the first cluster are highly heterogeneous and have greater structural complexity than beaches. For instance, submerged trunks and roots in flooded forests and patches of shrubs, and submerged woody debris in lagoon channels and streams, provide shelter and could enhance the potential for higher fish diversity. Indeed, in an experimental study, woody debris was found to correlate with fish species density through the enhancement of camouflage and shelter (Angermeier \& Karr, 1984). Furthermore, the stream presented unique characteristics among the sampled habitats; it was the deepest habitat within the lake, had low water temperature, high current, and it was strongly affected by local rainfall. These characteristics may have also been responsible for the highest species diversity encountered in the stream during the study, which was influenced by a suite of species not caught in other habitats of the lake (i.e., Hypophthalmus edentatus, Leporinus friderici, Pellona castelneana, Pimelodus. blochii, Triportheus angulatus, and T. pictus). 
Extensive beaches were formed along shorelines lacking vegetation when the water receded, and when flood, they maintained a low water. As mentioned above, this newly formed habitat was rapidly colonized by terrestrial herbaceous vegetation, but also by aquatic birds, turtles and caimans that use beaches for nesting during the low water (Petermann, 1997; Junk \& Da Silva, 1997). Thus beaches could potentially become nutrient enriched by fecal depositions of these nesting animals (e.g. Fittkau, 1970, 1973), which in nutrient-depleted systems, such as Taraira Lake, could significantly enhance primary productivity with effects cascading to upper trophic levels. Although fishes are more concentrated and therefore easy to catch during the low-water season, the largest fish biomass found in beaches during the low- and risingwater seasons, was primarily contributed by large, mainly piscivorous species, such as payara (H. scomberoides), pike characins (B. cf. cuvieri), arawana (Osteoglossum bicirrossum) and catfishes (H. platyrhynchos and $P$. fasciatum). Furthermore, several of the species caught at beaches had ripe gonads (i.e. C. monoculus, Satanoperca juruparu, M. rubripinni, O. niger, and S. rhombeus), and the detritivore catfish cuyu-cuyú (O. níger) was observed spawning at beaches (Correa, 1999).

During the falling-water season, fishes were highly dispersed in the inundated area which makes efficient sampling difficult. Total catches (both abundance and biomass) from lagoon channels and isolated shrub patches were the lowest among the habitats sampled during this season. These low catches could have influenced the outcome of the CA ordination in which lagoon channels and isolated shrub patches were separated. Nevertheless, seasonal variation in species composition between falling- and rising-water seasons has also been observed in fish communities of other regions (Saint-Paul et al., 2000; Galacatos et al., 2004).

The large rock patches represented a unique habitat in the lake. Species richness was comparatively low with respect to other habitats; however, sampling of this habitat with gill nets may not have been appropriate, since more species were caught with hook and line (9 species) than with the large gill net (3 species). Five of the species caught with hook and line were cichlids. Rock crevices could make this habitat suitable for nesting, particularly by cichlids. Two of the species caught from the rock parches with gill nets ( $C$. monoculus and $S$. rhombeus) were two of the most abundant species in the lake. Thus, it is unclear what caused the separation of the assemblage of this habitat from those of the others.

In conclusion, although strong hydrological seasonality in Taraira Lake results in seasonal fluctuation in fish abundances, assemblage structure seems to be maintained across seasons, which suggest strong species habitat affinities. Even though this is a descriptive study that did not include small species, the results presented here and in a previous report
(See Correa, 2003 for a checklist) are the first to document the species richness and ecological interactions of the ichthyofauna of the Lower Apaporis River. The Lower Apaporis is a very interesting region for the study of geographical distributions of South America freshwater fishes. The Apaporis is a lowland river that originates in alluvial savannas, and the lower portion of the river passes through the western edge of the Guyana Shield. Thus, the fish fauna of the lower Apaporis could be a transition zone with species broadly distributed in the western and eastern Amazon, but also with species more closely allied to the fauna of the Orinoco or Guyana basins.

\section{Acknowledgments}

I thank Sara Bennett and Ian Stephen for advice during the field work, Juan Carlos Botello for his support and friendship during field work, and Norberto Yucuna for field assistance. Kirk Winemiller, Lauren Chapman, Donovan German, and two anonymous reviewers provided valuable comments and suggestions on the manuscript. John Baker edited sections of the final version of the manuscript. Field work was supported by Fundación Omacha and Tropenbos-Colombia.

\section{Literature Cited}

Angermeier, P. L. \& J. R. Karr. 1984. Relationships between woody debris and fish habitat in a small warm water stream. Transactions of the American Fisheries Society, 115:716-726.

Araujo-Lima, C. A. R. M. \& M. Goulding. 1997. So Fruitful a Fish: Ecology, Conservation and Aquaculture of the Amazon's Tambaqui. New York, Columbia University Press, 191p.

Arrington, D. A., K. O. Winemiller \& C. A. Layman. 2005. Community assembly at the patch scale in a species rich tropical river. Oecologia, 144:157-167.

Barthem, R. \& M. Goulding. 1997. The Catfish Connection: Ecology, Migration and Conservation of Amazon Predators. New York, Columbia University Press, 144p.

Botello, J. C. 2000. Ecología y comportamiento del Lobo de Río Pteronura brasiliensis en la región del bajo Río Apaporis, Amazonia Colombiana. Unpublished BSc. Thesis. Universidad del Valle, Cali, 105p.

Correa, S. B. 1999. Estudio ecológico preliminar de asociaciones de peces en el Lago Taraira, Amazonia Colombiana. Unpublished BSc. Thesis. Universidad del Valle, Cali, 93p.

Correa, S. B. 2003. Ichthyofauna of lago Taraira, Lower Rio Apaporis sytem, Colombian Amazon. Dahlia, 6:59-68.

Correa, S. B., K. Winemiller, H. López-Fernández \& M. Galetti. 2007. Seed consumption and dispersal by fishes -evolutionary perspectives. BioScience, 57:748-756.

Cox Fernandes, C. 1998. Detrended canonical correspondence analysis (DCCA) of electric fish assemblages in the Amazon. Pp. 21-39. In: A. L. Val \& V. M. F. Almeida-Val, (Eds.). Biology of Tropical Fishes. Manaus, INPA, 460p.

Defler, T. R. 1996. Aspects of the ranging pattern in a group of wild woolly monkeys (Lagothrix lagothricha). American Journal of Primatology, 38:289-302. 
Domínguez, O. C. 1975. El Río Apaporis, visión antropogeográfica. Revista Colombiana de Antropología, 18:131-181.

Fittkau, E. J. 1970. Role of caimans in the nutrient regime of mouthlakes of Amazon affluents (an hypothesis). Biotropica, 2:138142.

Fittkau, E. J. 1973. Crocodiles and the nutrient metabolism of Amazonian waters. Amazoniana, 4:103-133.

Galacatos, K., R. Barriga-Salazar \& D. J. Stewart. 2004. Seasonal and habitat influences on fish communities within the lower Yasuni River basin of the Ecuadorian Amazon. Environmental Biology of Fishes, 71:33-51.

Galacatos, K., D. J. Stewart \& M. Ibarra. 1996. Fish community patterns of lagoons and associated tributaries in the Ecuadorian Amazon. Copeia, 4:875-894.

Gauch, H. G. J. \& R. H. Whittaker. 1981. Hierarchical classification of community data. The Journal of Ecology, 69:537-557.

Goulding, M. 1980. The Fishes and the Forest: Explorations in the Amazonian Natural History. Berkeley, University of California Press, 280p.

Goulding, M., M. L. Carvalho \& E. G. Ferreira. 1988. Rio Negro, rich life in poor water. The Hague, SPB Academic Publishing, 200p.

Goulding, M., N. J. H. Smith \& D. J. Mahar. 1996. Floods of Fortune: Ecology and Economy Along the Amazon. New York, Columbia University Press, 194p.

Grossman, G. D., J. E. Down \& M. Crawford. 1990. Assemblage stability in stream fishes: A review. Environmental Management, 14:661-671.

Hill, M. O. \& H. G. J. Gauch. 1980. Detrended correspondence analysis, an improved ordination technique. Vegetatio, 42:4758.

Hubert, N. \& J.-F. Renno. 2006. Historical biogeography of South American freshwater fishes. Journal of Biogeography, 33:14141436.

Huston, M. A. 1994. Biological Diversity: the Coexistence of Species in Changing Landscapes. Cambridge, Cambridge University Press, 701p.

Ibarra, M. \& D. J. Stewart. 1989. Longitudinal zonation of sandy beach fishes in the Napo River basin, Eastern Ecuador. Copeia, 2:364-381.

Junk, W. J. 1985. Temporary fat storage, an adaptation of some fish species to the water level fluctuations and related environmental changes of the Amazon river. Amazoniana, 4:315-351.

Junk, W. J. 1997. General aspects of floodplain ecology with special reference to Amazonian floodplains. Pp. 3-20. In: W. J. Junk, (Ed.). The Central Amazon Floodplain, Ecology of a Pulsing System. Berlin, Springer-Verlag, 525p.

Junk, W. J., P. B. Bayley \& R. E. Sparks. 1989. The flood pulse concept in river-floodplain systems: Proceedings of the International Large River Symposium. Canadian Special Publication of Fisheries and Aquatic Sciences. 106:110-127.

Junk, W. J. \& V. M. Da Silva. 1997. Mammals, reptiles and amphibians. Pp. 409-417. In: W. J. Junk, (Ed.). The Central Amazon Floodplain, Ecology of a Pulsing System. Berlin, Springer-Verlag, 525p.

Junk, W. J., M. G. M. Soares \& F. M. Carvalho. 1983. Distribution of fish species in a lake of the Amazon river flooplain near Manaus (Lago Camaleão) with special reference to extreme oxygen conditions. Amazoniana, 7:397-431.
Junk, W. J., M. G. M. Soares \& U. Saint-Paul. 1997a. The fish. Pp. 385-408. In: W. J. Junk, (Ed.). The Central Amazon Floodplain, Ecology of a Pulsing System. Berlin, Springer-Verlag, 525p.

Junk, W. J., M. G. M. Soares \& U. Saint-Paul. 1997b. Structure and function of the large Central Amazonian River floodplains: synthesis and discussion. Pp. 455-472. In: W. J. Junk, (Ed.). The Central Amazon Floodplain, Ecology of a Pulsing System. Berlin, Springer-Verlag, 525p.

Kenney, A. J. \& C. J. Krebs. 2000. Ecological Methodology. Department of Zoology, University of British Columbia, Vancouver.

Krebs, C. J. 1999. Ecological Methodology. Second edition. Menlo Park, CA, Benjamin Cummings, 620p.

Layman, C. A. \& K. O. Winemiller. 2004. Size-based responses of prey to piscivore exclusion in a species-rich Neotropical river. Ecology, 85:1311-1320.

Legendre, P. \& L. Legendre. 1998. Numerical Ecology. Second edition. Amsterdam, Elsevier Science, 870p.

Lowe-McConnell, R. H. 1979. Ecological aspects of seasonality in fishes of tropical waters. Symposia of the Zoological Society of London, 44:219-241.

Lowe-McConnell, R. H. 1987. Ecological Studies in Tropical Fish Communities. Cambridge, Cambridge University Press, 382p.

McCune, A. R. \& J. B. Grace. 2002. Analysis of Ecological Communities. Gleneden Beach, MjM Software.

McCune, B. \& M. J. Mefford. 1999. PC-ORD. Multivariate Analysis of Ecological Data. Gleneden Beach, MjM Software, 300p.

Mielke, P. W., Jr. 1984. Meteorological applications of permutation techniques based on distance functions. Pp. 813-830. In: P. R. Krishnaiah \& P. K. Sen, (Eds.). Handbook of Statistics, Elsevier Science Publishers, 968p.

Minchin, P. R. 1987. An evaluation of the relative robustness of techniques for ecological ordination. Vegetatio, 69:89-107.

PAT, 1997. Zonificacion ambiental para el plan modelo ColomboBrasilero (Eje Apaporis-Tabatinga: PAT). Bogotá, Instituto Agustin Codazzi (IAC).

Petermann, P. 1997. The birds. Pp. 420-452. In: W. J. Junk, (Ed.). The Central Amazon Floodplain, Ecology of a Pulsing System. Berlin, Springer-Verlag, 525p.

Petry, P., P. B. Bayley \& D. F. Markle. 2003. Relationships between fish assemblages, macrophytes and environmental gradients in the Amazon River floodplain. Journal of Fish Biology, 63:547579.

Poff, N. L. \& J. D. Allan. 1995. Functional organization of stream fish assemblages in relation to hydrological variability. Ecology, 76:606-627.

Rodriguez, M. A. \& J. W. M. Lewis. 1997. Structure of fish assemblages along environmental gradients in floodplain lakes of the Orinoco River. Ecological Monographs, 67:109-128.

Saint-Paul, U., J. Zuanon, M. A. V. Correa, M. Garcia, N. N. Fabre, U. Berger \& W. J. Junk. 2000. Fish communities in central Amazonian white- and blackwater floodplains. Environmental Biology of Fishes, 57:235-250.

Soares, M. G. M., R. G. Almeida \& W. T. Junk. 1986. The trophic status of the fish fauna in Lago Camaleao, a macrophyte dominated floodplain lake in the middle Amazon. Amazoniana, 9:511-526. 
Stewart, D. J., M. Ibarra \& R. B. Barriga-Salazar. 2002. Comparison of deep-river and adjacent sandy-beach fish assemblages in the Napo River Basin, Eastern Ecuador. Copeia, 2002(2):333-343.

Ter Braak, C. J. F. 1986. Canonical Correspondence Analysis: A New Eigenvector Technique for Multivariate Direct Gradient Analysis. Ecology, 67:1167-1179.

Werner, E. E. \& D. J. Hall. 1976. Niche shifts in sunfishes: experimental evidence and significance. Science, 191:404-406.

Winemiller, K. O. 1996. Dynamic diversity in fish assemblages of tropical rivers. Pp. 99-134. In: M. L. Cody \& J. A. Smallwood, (Eds.). Long Term Studies of Vertebrate Communities. London, Academic Press, 597p.

Accepted February 2008

Published June 28, 2008 